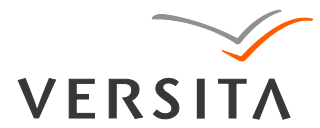

GEOCHRONOMETRIA 40(1) 2013: 22-32

DOI 10.2478/s13386-012-0025-1

Available online at

www.springerlink.com

\title{
PECULIARITIES OF SEDIMENTATION CONDITIONS IN THE OXBOW LAKES OF DUBYSA RIVER (LITHUANIA)
}

\author{
ALGIRDAS GAIGALAS ${ }^{1}$, ANNA PAZDUR ${ }^{2}$, ADAM MICHCZYNSKI ${ }^{2}$, JACEK PAWLYTA ${ }^{2}$, \\ ARŪNAS KLEIŠMANTAS ${ }^{1}$, MONIKA MELEŠYTE் ${ }^{1}$, EUGENIJA RUDNICKAITE் ${ }^{1}$, \\ VAIDOTAS KAZAKAUSKAS ${ }^{3}$, JULIUS VAINORIUS ${ }^{3}$ \\ ${ }^{l}$ Department of Geology and Mineralogy, Vilnius University, Ciurlonio 22/27, 2009 Vilnius, Lithuania \\ ${ }^{2}$ Institute of Physics, Silesian Technical University, Krzywoustego 2, 44-100 Gliwice, Poland \\ ${ }^{3}$ Institute of Geology and Geography of Nature Research Centre, Ševčenkos 13, LT-03223 Vilnius, Lithuania
}

Received 5 January 2011

Accepted 14 November 2012

\begin{abstract}
Abundant wood remains and buried trees have been found in the western part of Lithuania near Zakeliškiai and Lyduvėnai on Dubysa River (a tributary of Nemunas River) where deposits are rich in organic remnants and buried soils. In Zakeliškiai and Skiručiai sections of Dubysa River oxbow sediments were investigated by various methods (dendrochronological, carbonate, granulometric, pollen and mollusc fauna analysis). In addition, these sections were dated using the radiocarbon method. Samples were collected from deposits of Dubysa River outcrops. The studied oxbow lakes have existed for more than 5 thousand years (from ca. $4300 \mathrm{BC}$ to $1000 \mathrm{AD}$ ). During this period organic rich deposits with trees and branches were formed in the oxbow lake. This indicates that at the end of Atlantic, during Subboreal and in the early Subatlantic periods there was a forest growing that contained mainly oaks which were falling down into an oxbow lake and later were covered by sandy and silty deposits. The granulometry of alluvial deposits, as well as the mixture of medium-grained sand and silt show different stages of Dubysa River palaeochannel formation: riverbed and oxbow lakes. Three climate warming cycles were revealed according to carbonate analysis data in all investigated sections. The rheophile thermophilous Holocene age molluscs species Bithynia tentaculata L., Unio cf. crassus Philipsson, Pisidium amnicum (Müller), Theodoxus fluviatilis (Linnaeus) have been found. The pollen composition and sequences have been divided into five local pollen assemblage zones (LPAZ) and described according to pollen spectra in each zone. In this way it is possible restore palaeoclimatic coherent evolution, trends and cyclical change.
\end{abstract}

Keywords: radiocarbon, Holocene, carbonate analysis, dendrochronology, granulometry, oxbow lakes, Dubysa, Lithuania.

\section{INTRODUCTION}

The research material in the form of sediments of the river valleys and oxbow lakes, wood remains, mollusc shells and buried trees was collected in the five sections of Zakeliškiai outcrop (Zakeliškiai-I-V) and Skiručiai outcrop (Dubysa River, Fig. 1). Zakeliškiai outcrop sections (I, II, IV and V) are located on the right while the section Zakeliškiai-III and Skiručiai outcrop are on the left bank of Dubysa River meanders, next to the Zakeliškiai village (Kelme district).

Corresponding author: J. Pawlyta

e-mail: jacek.pawlyta@polsl.pl 


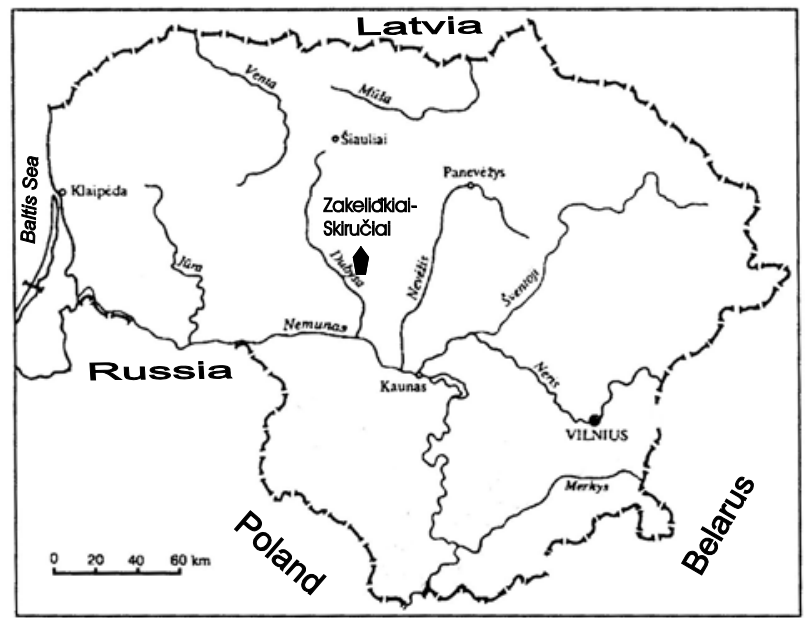

Fig. 1. Location map of the investigated Zakeliškiai and Skiručiai outcrops sections.

Buried tree trunks were found in oxbow lake deposits (Dubysa River) in the different sections. Radiocarbon dating results confirmed their Holocene origin. All the dates suggest that the samples were formed during Atlantic-Subboreal and early Subatlantic climatic periods (from ca. 5365 to $950 \mathrm{BC}$ ).

The granulometric analysis shows that the tree trunks were buried in the alluvial deposits, which are lying on the surface of the basal horizon and were formed by valley or oxbow lakes flood plain. Some tree trunks occurred in the deposits, may have been attributed to with its relationship the river valley deposits while the others of them fell into the oxbow lake. The darker layers of the oxbow lake hummus alluvium material are mixed with the lighter interlayers which were deposited during floods and contain fine sand. The granulometry of alluvial deposits as well as the mixture of middle-grained sand and silt show different stages of Dubysa River palaeochannel formation: riverbed (more sandy deposits) and oxbow lakes (more silty deposits).

\section{METHODS AND RESULTS}

\section{Sites and sampling}

During the expedition six geological sections were studied: Zakeliškiai outcrop sections I, II, III, IV and V and Skiručiai outcrop (one section). In the outwash above flood plane terrace oxbow lake sediments were found. They are mostly sandy with humus and wood remnants (Fig. 2). Lithology of the first four Zakeliškiai outcrop sections are shown in the Fig. 5.

\section{Zakeliškiai outcrop $\left(55^{\circ} 34.40^{\prime} \mathrm{N}, 23^{\circ} 4.20^{\prime} \mathrm{E}\right)$}

Section I. The height of the outcrop is $3.10 \mathrm{~m}$ above water level of Dubysa River. The altitude is $71.7 \mathrm{~m}$. Seven samples were collected from this section for radiocarbon dating.

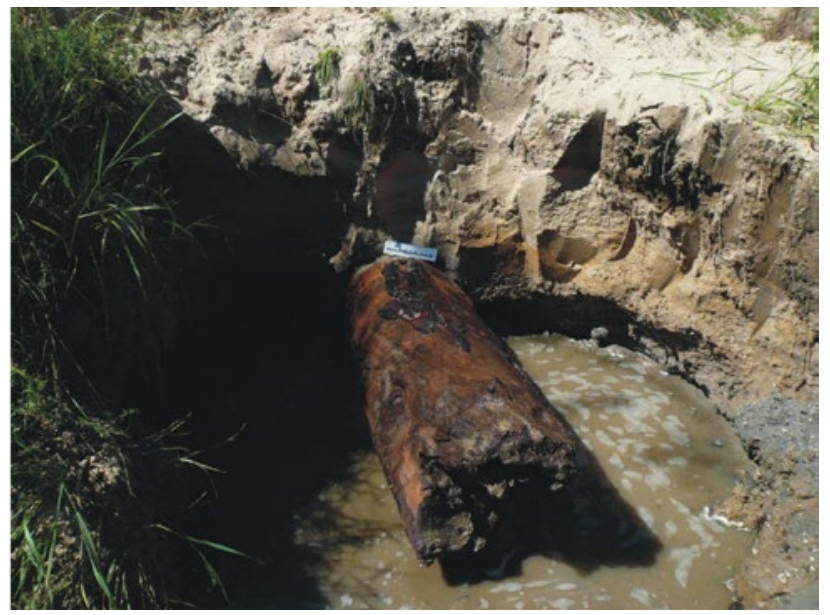

Fig. 2. Oak trunks in the lower part of oxbow-lake sediments.

Section II. The height of the outcrop is $3.50 \mathrm{~m}$ above Dubysa River water level. The altitude is $72.1 \mathrm{~m}$. Nine samples were collected from this section for granulometric analysis, 23 samples for pollen analysis, 23 samples for carbonate analysis and one sample for radiocarbon dating.

Section III. The height of the outcrop is $3.75 \mathrm{~m}$ above Dubysa River water level. The altitude is $71.41 \mathrm{~m}$. One sample was collected for radiocarbon dating from this section.

Section IV. The height of the outcrop is $3.80 \mathrm{~m}$ above Dubysa River water level. The altitude is $71.50 \mathrm{~m}$. One sample was collected for radiocarbon dating from this section.

Section V. The height of the outcrop is $3.95 \mathrm{~m}$ above Dubysa River water level. The altitude is $71.71 \mathrm{~m} .30$ samples for carbonate analysis were collected from this section.

\section{Skiručiai outcrop $\left(55^{\circ} 32.20^{\prime} \mathrm{N}, 23^{\circ} 4.50^{\prime} E\right)$}

The outcrop is located about $2 \mathrm{~km}$ north from Lyduvenai town. The height is $3.50 \mathrm{~m}$ above the water level of Dubysa River. The altitude is $68.20 \mathrm{~m}$. The first terrace over floodplane constitutes of the sandy sediments, which are overlaid by buried soil layer. Nine samples were collected for granulometric analysis, 18 samples for carbonate analysis and some shellfish remnants were collected for malacological investigations.

To study Dubysa River valley outcrops more precisely several research methods have been applied. The integrated studies gave us to an opportunity to obtain broader and more reliable information which helped in the interpretation of the data.

Analysis of lithological composition, texture, nature of contacts, inserts and sampling for laboratory investigations were carried out in the outcrops during field work. 


\section{Texture analysis}

Almost all the samples studied were predominantly sand fractions ( 1 to $0.5 \mathrm{~mm}$, from 0.5 to $0.25 \mathrm{~mm}$, and 0.25 to $0.1 \mathrm{~mm})$. The lower layers of the investigated sections (Table 1) were composed predominantly by gravel-pebble deposits with small boulders (9-th sample of Zakeliškiai outcrop section I and the 9-th sample of Skiručiai outcrop). The deposit types distinguished on the basis of 20 fractions of texture analysis results were grouped into eight categories: medium gravel, fine gravel, coarse-grained sand, middle-grained sand, fine-grained sand, coarse-grained silt, fine silt and clay according to the relevant lithological definitions. As highlighted in Table 1 the maximum amount of pebble-stone for both studied sections occurs in the lower parts and indicates that sedimentation of these deposits layers took place in strong water flow environment.

The maximum of fine sand and silt fractions were found in Zakeliškiai outcrop Section I between 0.25 and $3.05 \mathrm{~m}$ (Table 1, samples No. 1-7). The sum of fine sand and silt fractions in these samples exceeds $70 \%$. This indicates that the material was formed either in a weak flow or in a lake in a quiet environment.

In the Skiručiai outcrop section the maximum proportion fine sand and silt fractions was found at the depth between 0.40 and $2.10 \mathrm{~m}$. In these samples fine sand and silt fractions, similarly to the Zakeliškiai outcrop section I, exceeds $70 \%$. It can be argued that the formation of these layers also took place in weak water flow conditions or in a lake in a quiet environment.

\section{Carbonate analysis}

The content of calcite and dolomite and their variation in the sediments were established (Fig. 3). The carbonate analysis was applied to 71 samples from 3 sections (Zakeliškiai outcrop Section I, Section V and Skiručiai outcrop) and average out at $10 \mathrm{~cm}$ intervals. The analysis of sediments was done according to the Shczierbina (1958) method improved by Rudnickaite (1980). The decrease of carbonates content is related to the decrease of climate temperature and reflected in the composition of vegetation (Rudnickaite, 2007). A calcimeter was used to determine $\mathrm{CO}_{2}$ volume. Not only mineral calcite, but also dolomite could be determined using this method. The carbonate content of sediments was determined for bulk samples of $50 \mathrm{~g}$. Samples were powdered and $0.2 \mathrm{~g}$ weighed for carbonate analysis. Five measurements were done for every sample.

Changes in of the content of calcite and dolomite in sediments are shown in Fig. 3. Climate changes and environmental conditions were distinguished according to visual evaluation of the carbonate data analysis. An in-

Table 1. Results of texture analysis of sediments from Zakeliškès outcrop sections I and II.

\begin{tabular}{|c|c|c|c|c|c|c|c|c|c|c|c|}
\hline \multirow[b]{2}{*}{ 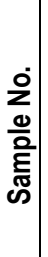 } & \multirow[b]{2}{*}{$\begin{array}{l}\text { छิ } \\
\text { 홍 } \\
\text { 옹 }\end{array}$} & \multicolumn{8}{|c|}{ Fractions $(\mathrm{mm})$} & \multirow[b]{2}{*}{$\begin{array}{c}\text { Sum } \\
(\%)\end{array}$} & \multirow[b]{2}{*}{ Aggregate name } \\
\hline & & 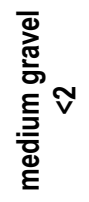 & 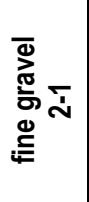 & 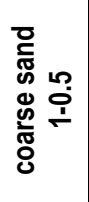 & 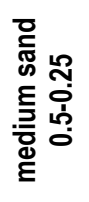 & 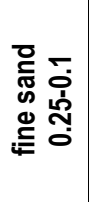 & 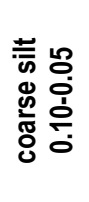 & 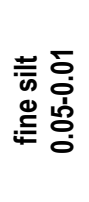 & $\begin{array}{l}\text { ¿ } \\
\text { v } \\
\frac{\pi}{0}\end{array}$ & & \\
\hline \multicolumn{12}{|c|}{ Zakeliškès I section } \\
\hline 1 & 0.40 & 0.00 & 0.03 & 0.43 & 22.36 & 62.11 & 12.09 & 2.98 & 0.00 & 100 & sand fine-grained with middle-grained sand and coarsely silt \\
\hline 2 & 0.70 & 0.01 & 0.00 & 0.14 & 4.40 & 57.32 & 26.62 & 9.43 & 2.08 & 100 & sand fine-grained with silt \\
\hline 3 & 1.30 & 0.05 & 0.60 & 7.20 & 15.02 & 40.85 & 25.72 & 7.84 & 2.72 & 100 & mixed-grained sand with silt \\
\hline 4 & 1.80 & 0.01 & 0.06 & 0.22 & 1.24 & 52.14 & 30.31 & 11.06 & 4.96 & 100 & sand fine-grained with mixed-grained silt, clayey \\
\hline 5 & 2.30 & 0.54 & 0.53 & 2.23 & 12.85 & 48.97 & 21.42 & 7.97 & 5.49 & 100 & mixed-grained sand, clayey \\
\hline 6 & 2.70 & 1.10 & 1.47 & 4.03 & 17.23 & 54.27 & 15.60 & 4.11 & 2.19 & 100 & sand fine-grained with silt \\
\hline 7 & 2.80 & 2.18 & 1.98 & 4.07 & 14.63 & 52.13 & 18.13 & 4.82 & 2.06 & 100 & sand fine-grained, coarse -grained silt and middle grained sand \\
\hline 8 & 3.15 & 16.50 & 13.22 & 11.13 & 30.17 & 23.62 & 2.01 & 3.35 & 0.00 & 100 & different grained sand, gravel \\
\hline 9 & 3.50 & 46.27 & 26.67 & 18.61 & 5.15 & 1.78 & 0.63 & 0.89 & 0.00 & 100 & gravel with coarse-grained sand \\
\hline \multicolumn{12}{|c|}{ Zakeliškès II section } \\
\hline 1 & 0.50 & 0.00 & 0.11 & 0.39 & 2.31 & 52.77 & 30.10 & 12.11 & 2.21 & 100 & sand fine-grained with course-grained and fine-grained silts \\
\hline 2 & 0.76 & 12.90 & 8.19 & 9.48 & 28.13 & 33.36 & 5.99 & 1.95 & 0.00 & 100 & different-grained sand with gravel \\
\hline 3 & 0.50 & 0.23 & 0.38 & 1.30 & 29.50 & 52.95 & 11.32 & 4.32 & 0.00 & 100 & sand fine-grained with middle-grained sand, silt \\
\hline 4 & 1.00 & 0.02 & 0.14 & 0.58 & 7.65 & 47.25 & 30.27 & 9.47 & 4.62 & 100 & sand different-grained with silt, clayey \\
\hline 5 & 1.35 & 0.00 & 0.00 & 0.12 & 9.90 & 75.98 & 12.65 & 1.35 & 0.00 & 100 & sand fine-grained with course-grained silt and middle-grained sand \\
\hline 6 & 1.75 & 0.00 & 0.00 & 0.18 & 31.62 & 66.58 & 1.40 & 0.22 & 0.00 & 100 & sand fine-grained with middle sand \\
\hline 7 & 2.60 & 0.21 & 0.31 & 2.54 & 37.82 & 44.29 & 12.43 & 2.40 & 0.00 & 100 & sand fine-grained with course-grained silt \\
\hline 8 & 3.20 & 1.72 & 14.07 & 38.34 & 35.32 & 10.40 & 0.11 & 0.04 & 0.00 & 100 & sand varied-grained with small gravel \\
\hline 9 & 3.50 & 29.67 & 26.18 & 20.38 & 14.43 & 7.08 & 1.19 & 1.07 & 0.00 & 100 & gravel with varied-grained sand \\
\hline
\end{tabular}



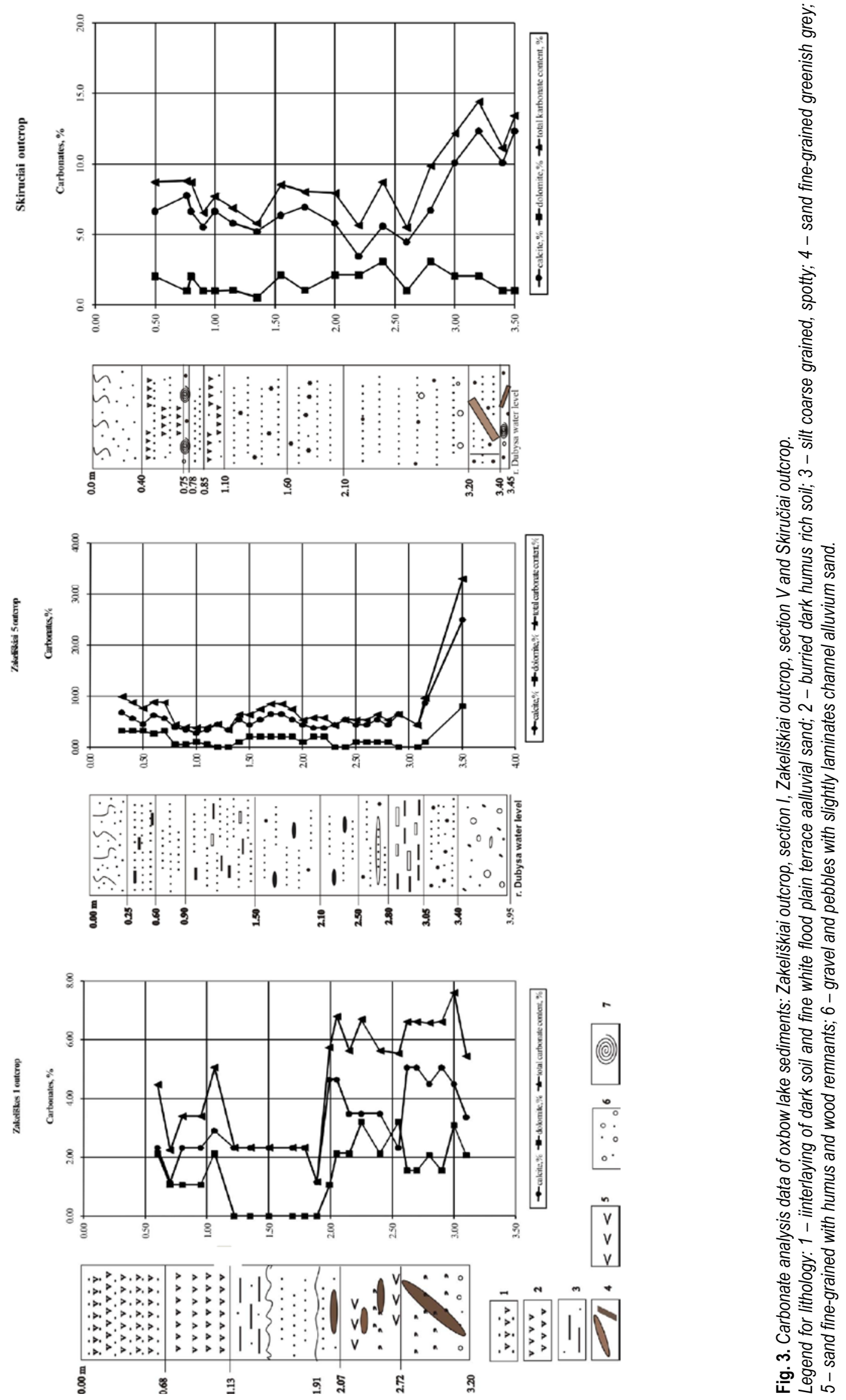
creasing percentage of carbonates were revealed at the depth of $0.5-1.22 \mathrm{~m}, 1.99-2.40 \mathrm{~m}$ and $2.62-3.10 \mathrm{~m}$ in Zakeliškiai outcrop Section I; 0.30-0.80 m, 1.40-2.00 m and $2.40-3.50 \mathrm{~m}$ in Zakeliškiai outcrop Section V; 0.5$1.10 \mathrm{~m}, 1.40-2.00 \mathrm{~m}$ and $2.80-3.50 \mathrm{~m}$ in the Skiručiai outcrop section. Comparing pollen and carbonates analysis data (Figs. 4 and 3), the increases in carbonate content are related mostly to warm climate periods in the Holocene. Buried soils in the oxbow lakes of Dubysa River sediments were revealed by small carbonate content increases (at depths $0.77-0.80 \mathrm{~m}$ and $2.40 \mathrm{~m}$ - Skiručiai outcrop; $1.20 \mathrm{~m}, 2.10 \mathrm{~m}$ and $2.70 \mathrm{~m}$ - Zakeliškiai outcrop Section I; $0.70 \mathrm{~m}, 1.2 \mathrm{~m}$ and $2.70 \mathrm{~m}$ - Zakeliškiai outcrop Section V). Lower values of carbonates were associated with colder climate periods.

According to carbonate data analysis three climate warming cycles have been found in three investigated outcrop sections: Zakeliškiai Sections I and V, as well as the Skiručiai Section. The climate and environmental conditions changes were distinguished according to peaks of the carbonate analysis data as well as compared to the pollen and molluscs analysis results (Table 4).

\section{Malacofauna studies}

Mollusc fauna has been described by Alexander Sanko (Minsk State Pedagogical University) and Simon Saarmann (Vilnius University, Department of Geology and Mineralogy). The studies have shown that in Zakeliškiai Sections II and V and Skiručiai outcrop the malacofauna are floundering and sparse, however they provide interesting information. The fauna found confirmed that the sediments in which it was found is a basal alluvium horizon. Usually this is a sparse, but dominant fauna species. Fate fauna is poor and consists of, very fragile shells of molluscs. This is due to air penetration of bulk sand-gravel sediment in layers in which the mollusc shell were burieds. A rheophile malacofauna was found. Widely distributed molluscs Bithynia tentaculata dependent (Linnaeus) to the family, which is characterized by freshwater, streaming waters (rivers, streams). These molluses lived in Atlantic period. Zakeliškiai crosssection rich of Unio cf. crassus Philipsson mollusc shells, Pisidium amnicum (Müller) mollusc shells mostly found in Skiručiai cross-section, at a depth of 0.75 to 0.78 above. The mentioned molluscs were living in later periods too (Damušyte, 2005; Sanko, 1999; Gaigalas et al., 2007).

The studied molluscs' taxonomic composition and shells preservation suggests that they really originate in the Holocene. The species are thermophilic. The Theodoxus fluviatilis (Linnaeus) belong to the Southern European species group, which came to Lithuania due to human activity, most likely during the Neolithic period ca. 5000 years ago (Damušyte, 2005). The mollusc species Pisidium amnicum (Müller) is dominant in the Skiručiai section.

\section{Pollen analysis}

A pollen analysis was carried out in 23 samples at the Zakeliškiai outcrop Section I The pollen diagram is shown in Fig. 4. The sediments for spores-pollen analysis were prepared following the standard technique (Erdtman, 1936; Grichuk, 1940). The total calculated number of trees and herbs pollen per sample reaches 500 terrestrial pollen grains and more. The pollen composition and sequences have been divided into five local pollen assemblage zones (LPAZ) and described according to pollen spectra in each zone:

1 LPAZ Pinus-Ulmus-Quercus-Tillia $(195-310 \mathrm{~cm})$. Herbaceous plants and shrub pollen is low, tree pollendominate and contribute $66 \%$ to the total. The prevailing species are pine $(25 \%)$, elm $(21 \%)$, oak $(12 \%)$ and lime $(8 \%)$. In the herbaceous pollen are cereals are most widely represented.

2 LPAZ Betula-Corylus $(150-195 \mathrm{~cm})$. Pollen zone with lower pollen concentration than the average. Tree species dominate $(60 \%)$. Among them are birch $(30 \%)$ and hazel $(23 \%)$. An increased content of shrubs, herbaceous plant pollen was found contributing up to $7 \%$ (mostly sedge and hardness). A small amount of pine, oak, hornbeam pollen was found in sediments from this interspace.

3 LPAZ Alnus $(125-150 \mathrm{~cm})$. Pollen concentration in these sediments is significantly reduced. Herbaceous plants dominate (44\%). Tree and shrub pollen occupy approximately the same concentration of the sample. In the interval found in willow, spruce, hornbeam, Poaceae, Cyperaceae, hardness, Ranunculaceae, dandelion, floats, hives, Filipendula pollen and Equisetum, polypody spores.

4 LPAZ Betula-Pinus $(100-125 \mathrm{~cm})$, pollen concentration also decreases in comparison to 3 LPAZ. Herbaceous plant pollen dominate (about $40 \%$ of total pollen). Found were $28 \%$ of birch, $11 \%$ of pine, alder, elm, lime pollen.

5 LPAZ Betula-Pinus-Alnus $(80-100 \mathrm{~cm})$. Pollen concentration is slightly decreased. Tree pollen dominate contributing $68 \%$ to the total: mostly birch $(21 \%)$, pine (18\%), alder (12\%). Herbaceous plants contribute $19 \%$. This is a zone of a very strong pine pollen concentration increase. Shrub and herb pollen spectra are quantitatively similar. The largest proportion of herbaceous plants and herbs belongs to Cyperaceae. There is a sizeable proportion of Ericales, sorrel, hardness.

The pollen composition and sequences have been described in terms of local pollen assemblage zones (LPAZ) at Zakeliškiai outcrop Section I in Table 2.

Pollen analysis is well reflected in the natural environmental conditions of a relatively large area and allows to interpret the climate change patterns and the nature of the above mentioned area. During the Atlantic period (Fig. 4, depth 310-190 cm) a number of thermophylic plants (elm, lime, oak, ash) increased. During a gradual warming of the climate broad-leaved forest developed 


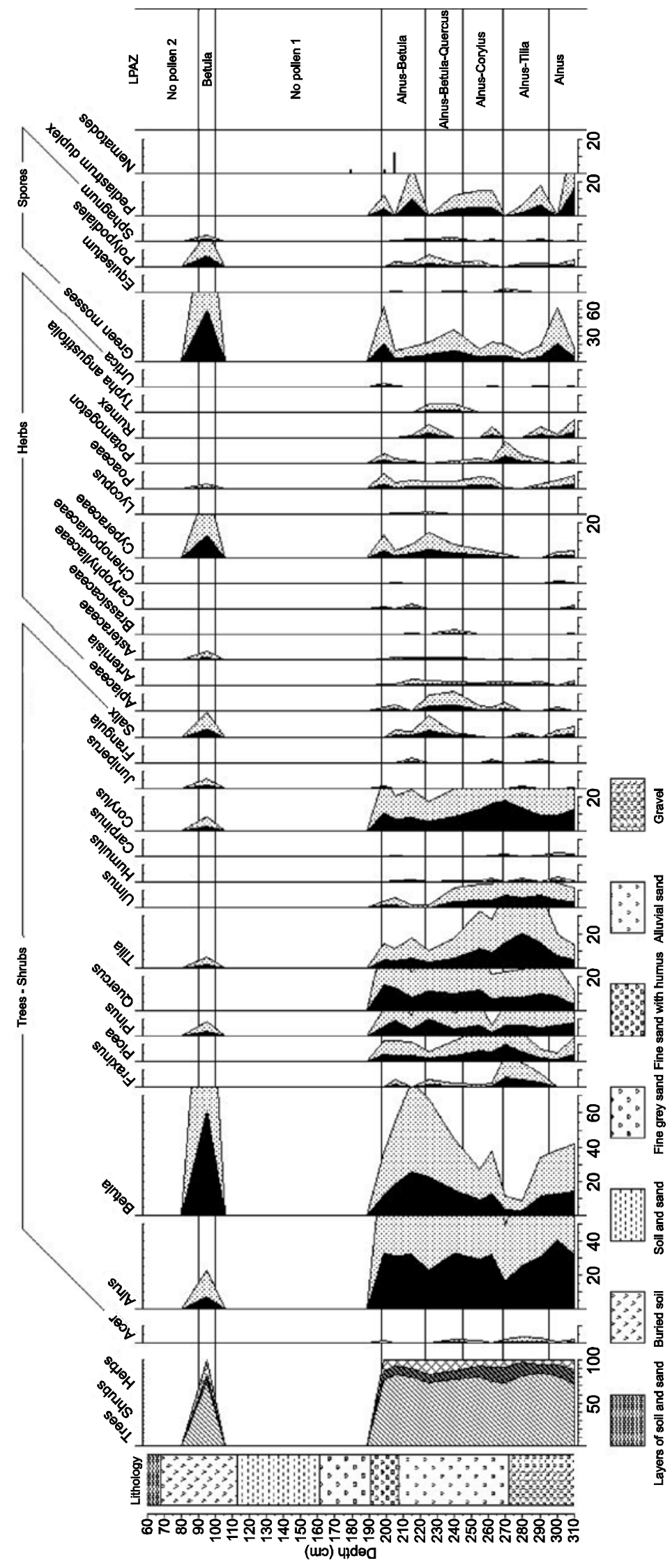

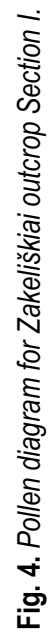


Table 2. Description of local pollen assemblage, Zakeliškiai outcrop Section I.

\begin{tabular}{lcl}
\hline LPAZ & Depth (cm) & Description of pollen zone \\
\hline No pollen 2 & $90-60$ & Occasional pollen of Betula, and spores of Polypodiales, Sphagnum. High concentrations of Charcoal. \\
\hline Betula & $100-90$ & $\begin{array}{l}\text { Peak of Betula (61.9\%), Cyperaceae (13.4\%), Salix (4.8\%) and green moss (61.1\%). } \\
\text { Limit: pollen concentration decrease }\end{array}$ \\
\hline No pollen 1 & $197-100$ & $\begin{array}{l}\text { Occasional pollen of Alnus, Corylus and Asteraceae. Some charcoal. Many spores of green moss. } \\
\text { Limit: rise of pollen concentration. }\end{array}$ \\
\hline Alnus-Betula & $223-197$ & $\begin{array}{l}\text { Alnus (32.7-31.5\%) and Betula (25.9-12.2) dominate. Peak of Quercus (7.6-15.2\%). Peak of nematodes. } \\
\text { Limit: pollen concentration decrease. }\end{array}$ \\
\hline Alnus-Betula-Quercus & $245-223$ & $\begin{array}{l}\text { Alnus dominate (22.9-33.2\%), Betula (22.7-15.0\%) increasing, Quercus in high numbers (11.3-10.0\%). } \\
\text { Peak of Pinus (4.6-9.9\%). Relatively high numbers of Cyperaceae (4.8-2.6\%) and Apiaceae (3.2-4.0\%). } \\
\text { Limit: rise of Betula. }\end{array}$ \\
\hline Alnus-Corylus & $268-245$ & $\begin{array}{l}\text { Alnus dominate (29.6-32\%). Pollen of broadleaf trees present in average numbers. } \\
\text { Corylus (12.5-16.4\%), Betula (8.9-12.6\%), Picea (6.5-5.7\%), Poaceae (2.2-2.4\%). } \\
\text { Limit: rise of herbs. }\end{array}$ \\
\hline Alnus-Tilia & $\begin{array}{l}\text { Peaks of Tilia (14.4-20.3\%), Corylus (18.0-9.2\%) Ulmus (7.7-6.3\%), Picea (2.4-10.0\%) and Potamo- } \\
\text { geton (4.4\%). Alnus dominate, but decrease (30.6-16.5\%). Minimum of Betula (11.4-3.8\%). } \\
\text { Limit: rise of Alnu. }\end{array}$ \\
\hline Alnus & $\begin{array}{l}\text { Alnus dominate (32.6-40.7\%), Betula (12.8-14.0\%), Corylus (9.4-13.0\%), high proportion of green moss- } \\
\text { es (5.2-20.8\%) and peak of green algae (16.0\%). } \\
\text { Limit: rise of Tilia and Fraxinus. }\end{array}$ \\
\hline
\end{tabular}

and the organic material in sediments increased (Kabailienè, 2006). At the end of the period of increased climate humidity alder forests became widespread around large water bodies ( $3 \mathrm{LPZ}$ ). At the end of the Atlantic and the beginning of Subboreal climate become cooler and dryer and meadows emerged. There were considerably fewer broad-leaved trees (lime, oak, elm) in the forest composition. Blond birch and pine forests became widespread.

At the beginning of Subatlantic forests lightened and became populated by pine, birch, alder grove. Herbs became more diverse. Cultural crops - wheat and rye microspore appear in the pollen spectrum, related to human economic activity. The landscape became more open. Humans, likely, contributed to environmental change, adapted the Dubysa River valley to theirs needs.

\section{Dendrochronology of fossil trunks}

More than 100 trees sank in the Dubysa River oxbow sediments between Zakeliškiai and Skiručiai villages were found. Identification of the species was based on investigations of wood structure on various sections. This was possible due to good preservation of pine and oak samples. Oak Quercus rubur L., the elm genus Ulmus sp. and Scots pine Pinus silvestris L. trees were recognized. Some trees were tested and dated by the radiocarbon method.

According to Gudelis (1973) during the Atlantic summer months, the average temperature was $2.5-3.5^{\circ} \mathrm{C}$ higher than now. Broad-leaved tree forests were much more common. Dendrochronometric investigations of Quercus robur L. trunkrevealed 77 very variable in thickness annual ring (Fig. 6A). The oak trunk was relatively thin (only $1.19 \mathrm{~cm}$ ). This shows that at the end of Atlantic the climate became cooler, deciduous trees grew in less favourable conditions. Elm genus Ulmus sp. L. counted 92 annual rings (Fig. 6B). Thin annual rings support the thesis that the trees grew in the prevailing adverse conditions.. Scots pine Pinus silvestris L. diameter was $35.3 \mathrm{~cm}$ and 99 annual rings were counted. The dendrochronogram is shown in Fig. 6C. According to dendrochronogram studies pine has grown rapidly only during the first eight years of its life. Subsequently, the growth rings are getting thinner and of variable thickness. Apparently weather conditions continued to deteriorate.

According to Gaigalas and Dvareckas (2002), Kabailiene (2006) and Gudelis (1973) at the end of warmer Atlantic period and the transition to Subboreal, the climate was cooler and had become unfavourable for sovereign broadleaf trees such as oak to grow. Our measurements are compatible with a previous dendrochronological research results.

\section{Radiocarbon dating of buried wood}

Radiocarbon dates (Table 3 ) were made on 8 wood and one charcoals samples collected in Dubysa River valley Zakeliškiai and Skiručiai outcrop sections.

Sample No.1 for ${ }^{14} \mathrm{C}$ dating (see Fig. 5, Section I) was taken from the soil of the lower part of the layer with thickness of $30 \mathrm{~cm}$ at the depth of 1.10 to $1.13 \mathrm{~m}$; sample No. 5 from elm trunk at the depth of 2.0 to $2.10 \mathrm{~m}$; sample No. 2 from a pine $\log$ of about $15 \mathrm{~cm}$ in diameter at the depth of 2.15 to $2.3 \mathrm{~m}$; sample No. 3 from willow trunk at the depth of 3.0 to $3.10 \mathrm{~m}$; sample No. 4 from deposits at the depth of 2.5 to $2.0 \mathrm{~m}$ (Fig. 5, Section I). Sample No.7 was taken from deposits at the depth of 3.3 to $3.75 \mathrm{~m}$. It is a wood trunk with $22 \mathrm{~cm}$ thickness. Section II is located $25-30 \mathrm{~m}$ downstream from section I. The tree trunk was lying in layered gravel at an angle of $23^{\circ}$ 
A. Gaigalas et al.

Table 3. Results of radiocarbon dating of wood samples from Zakeliškès outcrop sections. The sampling points - see Fig. 5. When identified species names are given below sample name.

\begin{tabular}{|c|c|c|c|c|c|}
\hline Section & $\begin{array}{c}\text { Sample name } \\
\text { (material) }\end{array}$ & Lab. No. & $\begin{array}{c}\mathrm{Age}^{14} \mathrm{C} \\
\text { (BP) }\end{array}$ & Calibrated age range $68 \%$ & Calibrated age range $95 \%$ \\
\hline I & $\begin{array}{c}\text { Zakeliškiai } \\
1 / 1.10 \mathrm{~m} \text { (charcoals) }\end{array}$ & Gd-20009 & $950 \pm 50$ & $\begin{array}{l}\text { 1025AD (19.0\%) 1056AD } \\
\text { 1076AD (49.2\%) 1154AD }\end{array}$ & $\begin{array}{c}997 \mathrm{AD}(1.1 \%) \text { 1005AD } \\
\text { 1012AD (94.3\%) 1208AD }\end{array}$ \\
\hline I & $\begin{array}{c}\text { Zakeliškiai } \\
2 / 2,15-2,30 \mathrm{~m} \text { (pine) }\end{array}$ & GdS-807 & $3530 \pm 40$ & $\begin{array}{l}\text { 1921BC (30.1\%) 1870BC } \\
\text { 1846BC }(21.4 \%) \text { 1810BC } \\
\text { 1804BC (16.7\%) 1776BC }\end{array}$ & 1965 (95.4\%) 1745 BC \\
\hline I & $\begin{array}{c}\text { Zakeliškiai } \\
3 / 3,0-3,1 \mathrm{~m} \text { (willow) }\end{array}$ & GdS-808 & $3360 \pm 40$ & $\begin{array}{c}1735 \mathrm{BC}(9.4 \%) 1714 \mathrm{BC} \\
1694 \mathrm{BC}(58.8 \%) \text { 1609BC }\end{array}$ & $\begin{array}{l}\text { 1742BC }(78.2 \%) \text { 1600BC } \\
\text { 1594BC }(17.2 \%) \text { 1531BC }\end{array}$ \\
\hline I & $\begin{array}{c}\text { Zakeliškiai } \\
4 / 2,5-2,75 \mathrm{~m} \text { (wood) }\end{array}$ & GdS-801 & $3280 \pm 30$ & $\begin{array}{l}\text { 1608BC (32.7\%) 1570BC } \\
1561 \mathrm{BC}(35.5 \%) 1518 \mathrm{BC}\end{array}$ & $\begin{array}{l}1631 \mathrm{BC}(94.3 \%) 1493 \mathrm{BC} \\
1473 \mathrm{BC}(1.1 \%) 1464 \mathrm{BC}\end{array}$ \\
\hline I & $\begin{array}{c}\text { Zakeliškiai } \\
5 / 2,0-2,10 \mathrm{~m} \text { (elm) }\end{array}$ & GdS-809 & $3430 \pm 40$ & $\begin{array}{l}1870 \mathrm{BC}(9.5 \%) 1846 \mathrm{BC} \\
1808 \mathrm{BC}(1.2 \%) 1805 \mathrm{BC} \\
1775 \mathrm{BC}(57.6 \%) 1683 \mathrm{BC}\end{array}$ & $\begin{array}{l}1879 \mathrm{BC}(13.6 \%) 1838 \mathrm{BC} \\
1830 \mathrm{BC}(81.8 \%) 1633 \mathrm{BC}\end{array}$ \\
\hline$\|$ & $\begin{array}{c}\text { Zakeliškiai } \\
7 / 3,35-3,50 \mathrm{~m} \text { (wood) }\end{array}$ & GdS-802 & $5365 \pm 35$ & $\begin{array}{l}\text { 4322BC }(16.0 \%) \text { 4291BC } \\
\text { 4266BC }(24.8 \%) \text { 4228BC } \\
\text { 4202BC }(17.9 \%) 4168 \mathrm{BC} \\
\text { 4127BC }(2.9 \%) 4120 \mathrm{BC} \\
\text { 4094BC }(6.6 \%) 4078 \mathrm{BC}\end{array}$ & $\begin{array}{l}4329 \mathrm{BC}(48.7 \%) 4221 \mathrm{BC} \\
4211 \mathrm{BC}(23.8 \%) 4150 \mathrm{BC} \\
4134 \mathrm{BC}(22.9 \%) 4054 \mathrm{BC}\end{array}$ \\
\hline III & $\begin{array}{c}\text { Zakeliškiai } \\
8 / 3,71-3,29 \mathrm{~m} \text { (oak) }\end{array}$ & GdS- 803 & $1750 \pm 30$ & $\begin{array}{l}242 \mathrm{AD}(17.8 \%) 265 \mathrm{AD} \\
272 \mathrm{AD}(50.4 \%) 335 \mathrm{AD}\end{array}$ & $216 \mathrm{AD}(95.4 \%) 390 \mathrm{AD}$ \\
\hline IV & $\begin{array}{c}\text { Zakeliškiai } \\
10 / 3,8-2,85 \mathrm{~m} \text { (wood) }\end{array}$ & GdS-804 & $1350 \pm 30$ & $650 \mathrm{AD}(68.2 \%)$ 680AD & $\begin{array}{c}636 \mathrm{AD}(87.7 \%) \text { 714AD } \\
744 \mathrm{AD}(7.7 \%) \text { 768AD }\end{array}$ \\
\hline IV & $\begin{array}{c}\text { Zakeliškiai } \\
\text { 9/3-4 m (wood) }\end{array}$ & GsS-573 & $3150 \pm 35$ & $\begin{array}{c}1491 \mathrm{BC}(7.0 \%) 1480 \mathrm{BC} \\
1456 \mathrm{BC}(61.2 \%) 1396 \mathrm{BC}\end{array}$ & $\begin{array}{l}1500 \mathrm{BC}(91.5 \%) 1376 \mathrm{BC} \\
1338 \mathrm{BC}(3.9 \%) \text { 1320BC }\end{array}$ \\
\hline
\end{tabular}
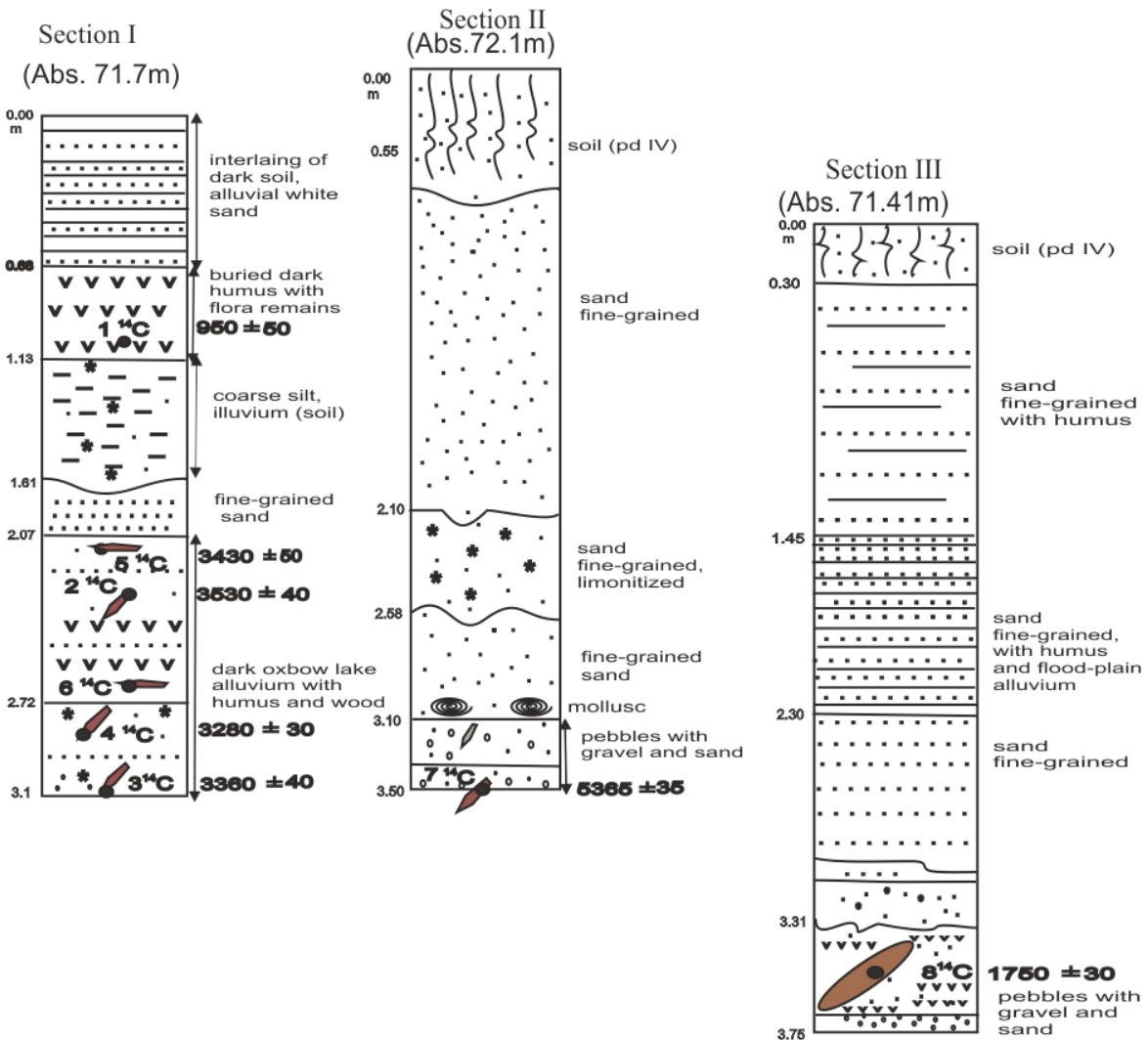

Section IV

(Abs. $71.50 \mathrm{~m}$ )

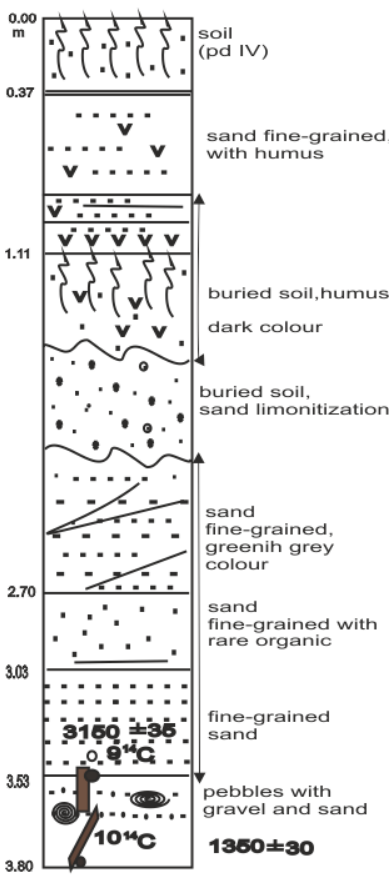

Fig. 5. Lithology of Zakeliškiai sections outcrop I, II, III and IV and results of radiocarbon dating. 

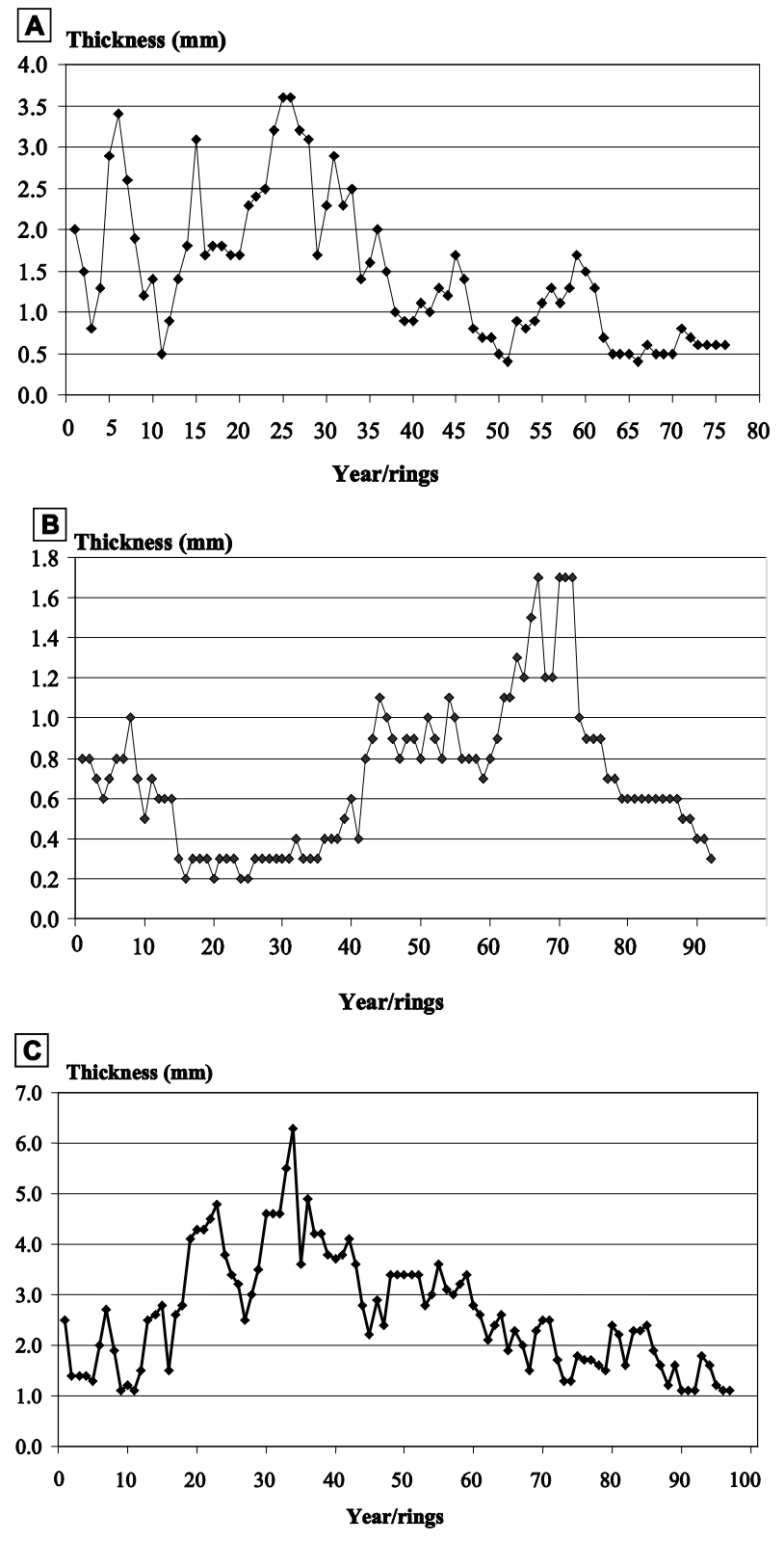

Fig. 6. Dendrograms of fossil trees: $A$ - common aok (Quercus robur L.), $B$ - elm genus (Ulmus sp. L.) and $C$ - scotch pines (Pinus Silvestras L.). All trunks recovered from oxbow lake sediments.

to the outcrop wall, protuberant about $15 \mathrm{~cm}$ above the Dubysa River water level (Fig. 5, section II). Sample No. 8 was taken from an oak trunk of a diameter of $43 \mathrm{~cm}$ at a depth 3.71 to $3.29 \mathrm{~m}$. (Fig. 5, section III). The third section is situated on the first terrace above floodplain terrace of Dubysa River left Bank. Sample No.10 was taken from pine trunk at a depth of 3.50 to $3.86 \mathrm{~m}$ (Fig. 5, section IV). Section IV is situated $35 \mathrm{~m}$ downstream from the third section on the first terrace above floodplain of Dubysa River right bank.
Radiocarbon dating was carried out in the Gliwice Radiocarbon Laboratory (Poland) by the LSC method (Pazdur et al., 2000 and 2003). Where possible, several outer rings of wood trunks were taken for radiocarbon dating. Calibration of radiocarbon dates was done using OxCal 4.1.7 software (Bronk Ramsey 2001) and Intcal09 radiocarbon calibration curve (Reimer et al. 2009). All of the obtained radiocarbon dates and their calibration results are provided in the Table 3 .

Atlantic - Subboreal - Subatlantic climatc events time-scale (Fig. 7) based on the results of oxbow lakes deposits radiocarbon dating was presented by Pawlyta et al. (2007). The data for radiocarbon dating of lakes, oxbow lakes, aeolian deposit layers were used to correlate the climate periods. The developed age-depth models confirmed the estimated climatic inversions Atlantic/Subboreal (ca. 3000 BC) and Subboreal/Subatlantic (ca. $500 \mathrm{BC}$ ) age periods.

The basal part of alluvium of the first terrace above floodplain of Dubysa River accommodate buried trunks of oak, which grew here at the end of the Atlantic climatic period, and was buried ca. $3000 \mathrm{BC}$. The warmest climatic period of Holocene - Atlantic period (ca. 5800$3000 \mathrm{BC}$ ), characterized by warmth loving mixed noble broadleaf tree forests. Oak, lime, elm, alder, hornbeam, and in underbrush, hazelnuts, grew during that time. Oaks, whose trunks from the Zakeliškiai outcrop sections were radiocarbon dated, grew at the warmest conditions during Atlantic climatic period. Oaks disappeared during the climatic transition to the Subboreal and were covered by more recent deposits. Oxbow lake deposits sedimented by Subatlantic were interfered with the present deposits. Oak trunks are black and hard-grained look iron like. Noble broadleaf tree forests at the Subboreal climate period (ca. 3000-500 BC) deteriorated due to the colder harsher weather conditions.

More significant latest climate change was during the Subatlantic climate period, which began ca. 500 BC. This is the beginning of the period of spreading of pine and alder woods, then colder period hit a second time and groves have been replaced by the modern times pine and birch.

Wood charcoals were found in the buried soil of the Dubysa River floodplain terrace sediments. This traces of human activity dated by radiocarbon and belongs to 950 $\mathrm{AD}$.

Stratigraphic subdivision and sedimentation conditions of investigated oxbow lakes deposits of Dubysa River was done using all available data, which enable to correlate different climate events (Table 4). Investigated sections explored in the timeline set and compared with each other. They fill the entire time interval during which different layers of sediments formed in an environment defined by climate. In this way it is possible to restore coherent palaeoclimatic evolution, trends and cyclical change. 


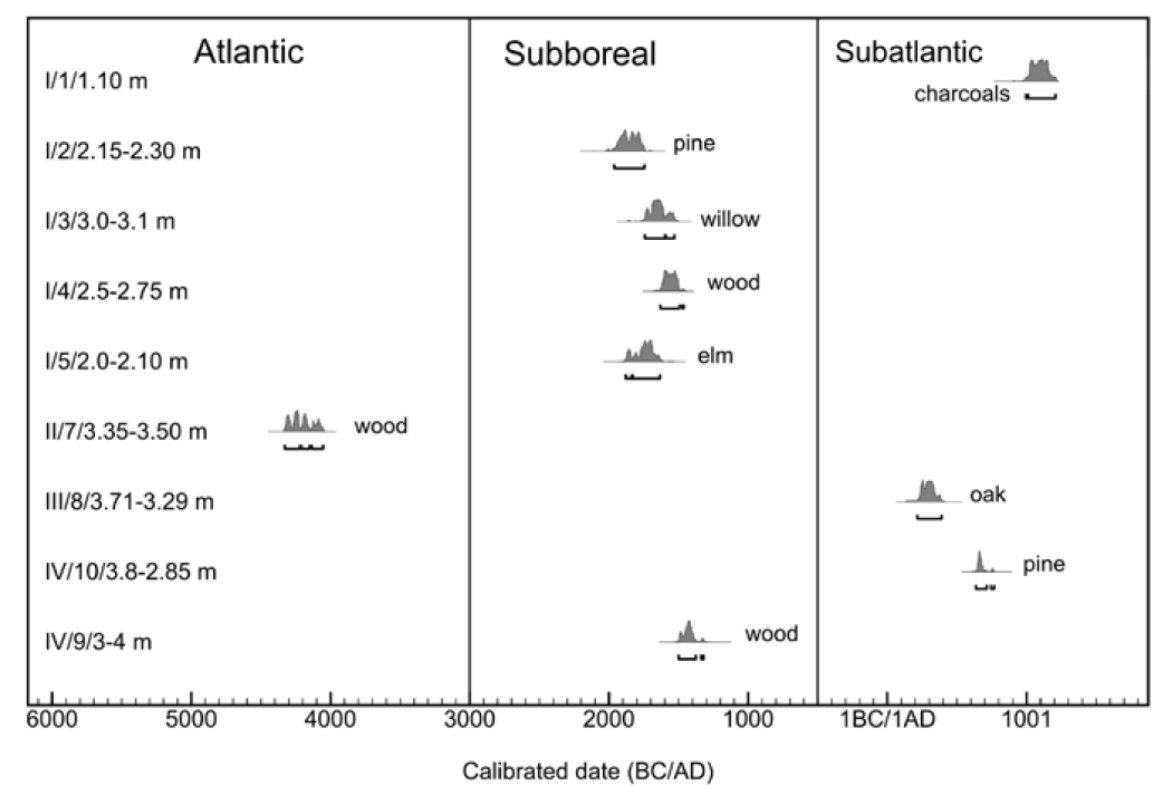

Fig. 7. Calibration results of all radiocarbon dates from Zakeliškiai outcrop and division to climatic periods according to chronozons from Table 4. Calibration of dates was made using IntCal09 curve (Reimer et al. 2009). Sample description contains section and sample numbers and depth (see Fig. 5 and Table 3).

Table 4. Stratigraphic subdivision and sedimentation conditions of investigated oxbow lakes deposits of Dubysa River.

\begin{tabular}{|c|c|c|c|c|c|}
\hline $\begin{array}{l}\text { Chronozones } \\
\text { (Pawlyta et al., } \\
\text { 2007) }\end{array}$ & $\begin{array}{l}{ }^{14} \mathrm{C} \text { Age } \\
\text { (BP) }\end{array}$ & $\begin{array}{c}\text { Trees investigated } \\
\text { by dendrometry } \\
\text { method }\end{array}$ & $\begin{array}{l}\text { Pollen analysis } \\
\text { (LPZ) }\end{array}$ & $\begin{array}{l}\text { Climatic conditions } \\
\text { on the basis of } \\
\text { carbonate analysis }\end{array}$ & Molluscs \\
\hline \multirow{3}{*}{$\begin{array}{c}\text { Subatlantic } \\
(1250 \mathrm{AD}-500 \\
\text { BC) }\end{array}$} & \multirow{3}{*}{$\begin{array}{l}950 \pm 50 \\
1350 \pm 30 \\
1750 \pm 30\end{array}$} & \multirow{3}{*}{ Oak Quercus robur L. } & 5 LPZ Betula-Pinus-Alnus & colder & \multirow{5}{*}{$\begin{array}{l}\text { Pisidium amnicum (Mǘller) - } \\
\text { rheophile }\end{array}$} \\
\hline & & & $\begin{array}{l}4 \mathrm{LPZ}(1.00-1.25 \mathrm{~m}) \\
\text { Betula-Pinus }\end{array}$ & warmer & \\
\hline & & & & \multirow{2}{*}{ colder } & \\
\hline \multirow[t]{2}{*}{$\begin{array}{c}\text { Subboreal } \\
(500-3000 \mathrm{BC})\end{array}$} & \multirow{2}{*}{$\begin{array}{l}3150 \pm 35 \\
3280 \pm 30 \\
3360 \pm 40 \\
3430 \pm 40 \\
3530 \pm 40\end{array}$} & \multirow[t]{2}{*}{$\begin{array}{l}\text { Elm genus Ulmus } L . \\
\text { Elm genus Ulmus } L \text {. }\end{array}$} & \begin{tabular}{|l|}
3 LPZ $(1.25-1.50 \mathrm{~m})$ \\
Alnus \\
2 LPZ $(1.5-1.95 \mathrm{~m})$ \\
Betula-Corylus \\
\end{tabular} & & \\
\hline & & & \multirow{3}{*}{$\begin{array}{l}1 \mathrm{LPZ}(1.95-3.10 \mathrm{~m}) \\
\text { Pinus-Ulmus-Quercus-Tillia }\end{array}$} & warmer & \\
\hline & & & & colder & \multirow[b]{2}{*}{$\begin{array}{l}\text { Bithynia tentaculata } \\
\text { (Linnaeus) - freshwater } \\
\text { runlets, rivulets, streemlets, } \\
\text { rivers; Unio cf. crassus } \\
\text { Philipson, Theodoxus fliuvatilis } \\
\text { (Linnaeus) }\end{array}$} \\
\hline $\begin{array}{c}\text { Atlantic } \\
(3000-5800 \mathrm{BC})\end{array}$ & $5365 \pm 35$ & $\begin{array}{c}\text { Common oak Quercus } \\
\text { robur } L .\end{array}$ & & warmer & \\
\hline
\end{tabular}

\section{CONCLUSIONS}

The studied oxbow lakes have existed for more than 5 thousand years (from ca. $4300 \mathrm{BC}$ to $1000 \mathrm{AD}$ ). During this period nearly $2 \mathrm{~m}$ of organics rich deposits with tree trunks (Zakeliškiai - Skiručiai band recorded more than 100 logs in heaps), branches and fruit remains have been formed in the oxbow lake. It indicates that perhaps in the end of Atlantic, during Subboreal and early Subatlantic a rich mixed forest flourished in Dubysa valley and trees (oaks mainly) were falling down into an oxbow lake just to be covered with deposits.
At the end of the Atlantic and beginning of Subboreal period climate become cooler and dryer. The meadows emerged. There were considerably less broad-leaved trees (lime, oak, elm) in forest composition. Blond birch and pine forests became widespread.

At the beginning of Subatlantic pine, birch and alder grove appeared. Herbs have become more diverse, Human activity affected river valley environment. Dendrochronograms show that Atlantic period provided the best conditions for growth of noble trees (oak).

The studied molluscs' taxonomic composition and shells survival suggests that they really belonged to the 
Holocene period. A rheophile malacofauna was found. The species are thermophilic.

The climate and environmental conditions changes were distinguished according to carbonate analysis data as well as compared to pollen and molluscs analysis results. Three climate warming cycles were found in investigated outcrop sections.

Investigated sections explored in the timeline set and compared with each other. They fill the entire time interval during which different layers of sediments formed in an environment defined by climate. In this way it is possible restore palaeoclimatic coherent evolution, trends and cyclical change.

\section{ACKNOWLEDGEMENTS}

The authors thanks prof. A. Sanko, PhD student S. Saarmann for tests performed malacofauna in Zakeliškiai and Skiručiai sections, Martynas Kazlauskas for pollen analysis. The study was partialy financed by The Research Council of Lithuania (grant No. LEK-03/2010).

\section{REFERENCES}

Bronk Ramsey C, 2001. Development of the radiocarbon calibration program OxCal. Radiocarbon 43(2A): 355-363.

Damušyte A, 2005. Fossil molluscs of the Lithuanian Baltic coast. Quaternary Geology and Landforming Processes. In: Proceedings of the International Field Symposium, Kola Peninsula, NW Russia, September 4-9, 2005. Apatity, 2005: 15-16.

Gaigalas A and Dvareckas V, 2002. The evolution of river valleys in Lithuania from deglaciation to recent changes and data from the sediment infill of oxbow lakes. Netherlands Journal of Geosciences (Geologie en Minjnbouw) 81(3-4): 407-416.

Gaigalas A, Sanko A, Pazdur A, Pawlyta J, Michczyński A and Budènaitè S, 2007. Buried oaks and malacofauna of Holocene oxbow lake sediments in the Valakupiai section, Lithuania. Geologija 58: $35-48$
Grichiuk VP, 1940. Processing of deposits poor in organic material for the pollen analysis. In: Grichiuk VP, Problems of the physical geography, Nauka, Moskva: 40-68 (In Russian).

Gudelis WK, 1973. Holocene sediments of Baltic zone. In: Reliefs and Quaternary sediments of Baltic zone: 195-209 (In Russian).

Erdtman G, 1936. New methods in pollen analysis. Svensk Botanisk Tidsskrift 30: 154-164.

Kabailienè M, 2006. Development of natural environment in Lithuania during 14000 years. Vilnius University, Vilnius: 471 (In Lithuanian).

Pawlyta J, Gaigalas A, Michczynski A, Pazdur A and Sanko A, 2007. Time scale for climatic events of Subboreal/Subatlantic transition Valakupiai site, Lithuania. Radiocarbon 49(2): 889-897.

Pazdur A, Fogtman M, Michczyński A and Pawlyta J, 2003. Precision of ${ }^{14} \mathrm{C}$ dating in Gliwice Radiocarbon Laboratory. FIRI Programme. Geochronometria 22: 27-40.

Pazdur A, Pawlyta J and Spahiu P, 2000. Comparison of the radiocarbon dating methods used in the Gliwice Radiocarbon Laboratory. Geochronometria 18: 9-13.

Reimer PJ, Baillie MGL, Bard E, Bayliss A, Beck JW, Blackwell PG, Bronk Ramsey C, Buck CE, Burr GS, Edwards RL, Friedrich M, Grootes PM, Guilderson TP, Hajdas I, Heaton TJ, Hogg AG, Hughen KA, Kaiser KF, Kromer B, McCormac FG, Manning SW, Reimer RW, Richards DA, Southon JR, Talamo S, Turney CSM, van der Plicht $J$ and Weyhenmeyer CE, 2009. IntCal09 and Marine09 radiocarbon age calibration curves, 0-50,000 years cal BP. Radiocarbon 51(4):1111-1150.

Rudnickaite EL, 1980. The technique of the determination of carbonates in various age Pleistocene tills. In: Raukas A. (Ed.), Methods of the field and laboratory investigations of glacial deposits. Abstracts of the symposium, Tallinn: 121 (In Russian).

Rudnickaite EL, 2007. Reconstruction of palaeogeography of Pleistocene interglacials according carbonates content. XVII INQUA Congress The Tropics: Heat Engine of the Quaternary, July 27 August 03, 2007, Cairns, Australia. Abstracts. Quaternary International 167-168, Supplement: 356, DOI 0.1016/j.quaint.2007.04.001.

Shczierbina V N, 1958. About the method of mass measurement of carbonates in sedimentary rocks. In: Trudy Instituta Geologicheskih Nauk AN BSSR 1, Minsk: 131-144 (In Russian).

Sanko A F, 1999. Malacofauna of Pleistocene and Holocene in Belarus. Minsk: 103 (In Russian) 